\title{
Loparite and 'metaloparite' from the Burpala alkaline complex, Baikal Alkaline Province (Russia)
}

\author{
A. R. Chakhmouradian ${ }^{1}$, R. H. Mitchell $^{1}$, A. V. Pankov ${ }^{2}$ and N. V. Chukanov $^{3}$ \\ ${ }^{1}$ Department of Geology, Lakehead University, 955 Oliver Road, Thunder Bay, Ontario, Canada P7B 5E1 \\ 2 Department of Mineralogy, St. Petersburg State University, 7/9 University Emb., St. Petersburg, Russia 199034 \\ ${ }^{3}$ Institute of Chemical Physics, Chernogolovka, Moscow Region, Russia 101026
}

\section{ABSTRACT}

Loparite-(Ce) is a ubiquitous accessory mineral in modally diverse albite-rich metasomatic rocks of the Burpala alkaline complex, Siberia. Compositionally, the mineral approaches the ideal formula $\mathrm{NaREETi}_{2} \mathrm{O}_{6}(R E E=\mathrm{Ce}>\mathrm{La}>\mathrm{Nd}>\mathrm{Pr}>\mathrm{Sm})$, and contains minor $\mathrm{CaTiO}_{3}\left(<4.8 \mathrm{~mol}_{0} \%\right), \mathrm{SrTiO}_{3}$ $(<4.7 \mathrm{~mol} . \%)$ and $\mathrm{NaNbO}_{3}(<6.4 \mathrm{~mol} . \%)$. The mineral is pseudocubic $\left[a_{\mathrm{p}}=3.8815(3) \AA\right]$, and produces an XRD pattern similar to that of synthetic $\mathrm{NaCeTi}_{2} \mathrm{O}_{6}[$ Pnma $, a=5.4517(4), b=7.7058(9), c=$ $5.4333(6) \AA]$. The atomic coordinates and isotropic thermal parameters of synthetic $\mathrm{NaCeTi}_{2} \mathrm{O}_{6}$ refined from an XRD powder pattern using the Rietveld method, are given. At Burpala, loparite precipitated from an alkaline $R E E$-rich fluid during the metasomatic alteration of earlier-formed intrusive rocks. In some parageneses, loparite was replaced by 'metaloparite' during the final stages of metasomatism. 'Metaloparite' has the empirical formula $\operatorname{REETi} \mathrm{T}_{2} \mathrm{O}_{6-x}(\mathrm{OH}, \mathrm{F})_{x} \cdot \mathrm{nH}_{2} \mathrm{O}$, and shows minor enrichment in $\mathrm{Ca}$ and depletion in $\mathrm{Sr}$, compared to co-existing loparite. The formation of 'metaloparite' involved cation leaching, hydration and ion-exchange between loparite and a fluid. 'Metaloparite' is metamict at room temperature, but some samples regain the perovskite-type structure upon heating.

KeYwords: loparite-(Ce), 'metaloparite', structure, albite metasomatites, Burpala complex, Baikal Alkaline Province.

\section{Introduction}

Complex titanates of alkaline and alkaline-earth elements have recently been studied extensively because of their potential use in ceramic nuclearwaste forms, and significance as repositories for the high field-strength and large-ion lithophile elements in the lower crust and upper mantle. Studies of naturally-occurring and synthetic titanates (Kesson et al., 1983, Gieré and Williams, 1992; Harley, 1994; Lumpkin and Ewing, 1996; Mitchell and Chakhmouradian, 1996, 1998a,b; and Chakhmouradian and Mitchell, 1998a) show that their structures are remarkably tolerant towards cationic substitutions involving the rare-earth $(R E E)$ and actinide $(A C T)$ elements, typical components of high-level radioactive waste (Ringwood et al., 1979). Significantly less information is available on the stability of the Ti-based REE-ACT hosts in various geological environments. There is a very limited number of experimental studies on the behaviour of these phases under hydrothermal conditions (Nesbitt et al., 1981; Myhra et al., 1984; Kastrissios et al., 1987), and mineralogical publications describing primary or secondary alteration of naturally-occurring titanates (Banfield and Veblen, 1992; Lumpkin and Ewing, 1996).

One of the most important REE-ACT hosts in alkaline rocks is loparite, a member of the perovskite mineral group (Mitchell, 1996; Mitchell and Chakhmouradian, 1996, 1998b; Chakhmouradian and Mitchell, 1997, 1998a). Naturally-occurring loparite exhibits a broad variation in major and minor components, including $\mathrm{Na}, \mathrm{REE}, \mathrm{Ca}, \mathrm{Sr}, \mathrm{Th}$, Ti and $\mathrm{Nb}$. Most compositions of this mineral can be adequately described in terms of four perovskite-type endmembers (Mitchell, 1996): loparite

(C) 1999 The Mineralogical Society 


\section{A. R. CHAKHMOURADIAN ETAL.}

$\left(\mathrm{NaREETi}{ }_{2} \mathrm{O}_{6}\right)$, perovskite $\left(\mathrm{CaTiO}_{3}\right)$, tausonite $\left(\mathrm{SrTiO}_{3}\right)$ and lueshite $\left(\mathrm{NaNbO}_{3}\right)$. In the majority of compositions, the lanthanides are strongly dominated by $L R E E$ and show the following LREE-distribution pattern: $\mathrm{Ce}>\mathrm{La}>\mathrm{Nd}>\mathrm{Pr}>$ $\mathrm{Sm}$. According to the principles of classification of REE-bearing minerals, such loparite should be termed loparite-(Ce). There are only a few compositions known in which $\mathrm{La}$ is the predominant element among the lanthanides, and which should be termed 'loparite-(La)' (Kopylova et al., 1997; Chakhmouradian and Mitchell, 1998a). However, at present, mineralogical studies of this phase are insufficient for the mineral name or species to be approved by the CNMMN of the IMA. In this work, we describe loparite-(Ce), rather than its La-analogue, and hereafter refer to this mineral simply as loparite.

Loparite most enriched in REE and depleted in minor elements $(\mathrm{Ca}, \mathrm{Sr}, \mathrm{Nb})$ occurs in alkaline rocks of the Burpala complex in northern Transbaikalia, Russia (Zhidkov, 1961a). Neither the chemistry of this mineral nor its structure have been studied in detail. The original data on the composition of loparite from Burpala were obtained by bulk wet-chemical methods and report unrealistically high $\mathrm{SiO}_{2}$ contents (8.2 wt.\%: Zhidkov, 1961a). Other studies (e.g. Khomyakov, 1972) present data only on the REE distribution in this loparite, confirming the typical pattern $\mathrm{Ce}>\mathrm{La}>\mathrm{Nd}>\mathrm{Pr}>\mathrm{Sm}$. These studies provide no information on the overall compositional variation of the mineral.

At Burpala, loparite is commonly replaced by a $R E E$-Ti phase which is referred to in the literature as 'metaloparite' (Portnov et al., 1981). In contrast to loparite, 'metaloparite' contains appreciable $\mathrm{H}_{2} \mathrm{O}$ and lacks alkalies (Gerasimovskii, 1941). 'Metaloparite' appears to be a fairly common product of loparite alteration in alkaline rocks. In addition to Burpala, it has been found in nepheline syenites and urtites of the Lovozero intrusion, Kola Peninsula (Gerasimovskii, 1941), amphibole-apatite rocks at the Enisei Ridge, Siberia (Saltykova, 1959), foyaite in the Poga complex, Russian Far East (Tolok and Bazhenova, 1965), nepheline syenite at Bratthagen, Norway, and Pegmatite Peak, Montana (Lumpkin et al., 1997; Chakhmouradian and Mitchell, unpubl. data), carbonatites of the Schryburt Lake complex, Ontario (R.G. Platt, pers. comm.). However, 'metaloparite' remains an inadequately studied phase both with respect to its composition and to its structure. Most compositional data on this mineral have been obtained by bulk 'wetchemical' methods, and only two microprobe analyses of 'metaloparite' from Bratthagen are available in the literature (Lumpkin et al., 1997). Also, it is probable that some 'metaloparite' pseudomorphs, particularly those described in the early studies, may actually represent intergrowths of several minerals, rather than being a single phase. The validity of 'metaloparite' as a distinct mineral species has been questioned by many researchers (e.g. Semenov, 1972). Consequently, this mineral first described at Lovozero by Gerasimovskii (1941), has not been approved as a valid name by the CNMMN IMA.

The current study was undertaken to assess the compositional variation of loparite and 'metaloparite' from the Burpala alkaline complex. We also attempted to study the structural characteristics of these minerals, on the basis of X-ray diffraction data and infrared spectroscopy.

\section{Occurrence}

The Burpala (Burpalinskii) complex $\left(56^{\circ} 33^{\prime} \mathrm{N}\right.$, $110^{\circ} 45^{\prime} \mathrm{E}$ ) is situated in Stanovoye Nagor'ye (south-central Siberia), $\sim 100 \mathrm{~km} \mathrm{NE}$ of the northern tip of L. Baikal. The complex belongs to the Baikal Alkaline Province and comprises alkaline igneous rocks of early Carboniferous age. The country rocks, mostly sandstones and siltstones of Precambrian and Lower Cambrian age, are fenitized in the vicinity of the intrusion (Zhidkov, 1961b; Kogarko et al., 1995). The Burpala complex has a concentric infrastructure, and is composed (from the contact inwards) of: quartz syenite, alkaline syenite (pulaskite) and nepheline syenite (foyaite) (Zhidkov, 1961b). Minor rock types include syenitic, nephelinesyenitic pegmatite, phonolite and lamprophyre dykes. The magmatic alkaline lithologies are commonly replaced by metasomatic albite and microcline rocks with variable amounts of aegirine and riebeckite. The pegmatitic and metasomatic rocks at Burpala are a source of many rare minerals, particularly titano- and zircono-silicates, and Ti-based oxides such as loparite, pyrophanite, murataite and landauite (Portnov et al., 1981; Merlino et al., 1990).

At Burpala, loparite is confined to areas of latestage alkaline metasomatism both within the intrusion and in the surrounding fenites. In this study, we examined loparite from modally diverse metasomatic rocks, including albite, microcline- 


\section{LOPARITE AND ‘METALOPARITE’ FROM RUSSIA}

riebeckite-albite, riebeckite-albite and fenite varieties. In all these assemblages, loparite forms interpenetration twins of hexahedral crystals ranging from $<1 \mathrm{~mm}$ to a few centimetres in size. Most twins poikilitically enclose numerous laths of microcline and albite. Other minerals commonly associated with loparite include aegirine, nepheline, zircon, ilmenite, eudialyte, catapleite and chevkinite.

'Metaloparite' is a product of replacement of loparite. In some parageneses, e.g. albitite, 'metaloparite' occurs as irregular spots within the loparite matrix, whereas in others, e.g. aegirinite, it forms complete pseudomorphs after loparite. The macroscopic colour of pseudomorphs ranges from dark brown to yellowish green, depending on the amount of unaltered loparite in the sample. In transmitted light, loparite is reddish brown and weakly anisotropic, whereas 'metaloparite' is yellowish green and shows strong anisotropism. In reflected light, loparite has somewhat higher reflection values, compared to 'metaloparite' (Table 1). 'Metaloparite' typically contains poikilitic inclusions of aegirine, albite, microcline, plus minor $R E E$ fluorocarbonates. The REE-fluorocarbonate inclusions do not occur in unaltered loparite, but are very common in the samples from aegirinites which contain the most altered yellowish green 'metaloparite' devoid of loparite relics. This may indicate that the replacement of loparite by

TABLE 1. Reflectance values (,$\%$ ) for loparite and 'metaloparite' from the Burpala complex

\begin{tabular}{lcc}
\hline$\lambda, \mathrm{nm}$ & Loparite & 'Metaloparite' \\
\hline 440 & 19.2 & 17.9 \\
460 & 18.4 & 17.4 \\
480 & 18.3 & 17.2 \\
500 & 17.6 & 16.8 \\
520 & 17.2 & 16.5 \\
540 & 17.0 & 16.3 \\
560 & 16.8 & 16.1 \\
580 & 16.5 & 16.0 \\
600 & 16.5 & 15.9 \\
620 & 16.3 & 15.8 \\
640 & 16.2 & 15.8 \\
660 & 16.2 & 15.6 \\
680 & 16.2 & 15.5 \\
700 & 16.0 & 15.4 \\
& &
\end{tabular}

Reflectance values measured on MSF-10 using $\mathrm{SiC}$ as a calibration standard. 'metaloparite' was accompanied by the crystallization of fluorocarbonates, mostly bastnäsite(Ce).

\section{Experimental methods}

Initially, wavelength-dispersion spectrometry was employed to determine the range of elements present in loparite and 'metaloparite' from Burpala. More than 30 analyses of both minerals were obtained by one of the present authors (RHM) using an automated CAMECA SX-50 electron microprobe operated at an accelerating voltage of $15 \mathrm{kV}$ or $20 \mathrm{kV}(R E E)$ and beam current of $20 \mathrm{nA}$ or $40 \mathrm{nA}$ (REE). The following standards were used: albite $(\mathrm{Na})$, almandine $(\mathrm{Fe})$, diopside $(\mathrm{Ca})$, microlite $(\mathrm{Ta})$, monazite $(\mathrm{Ce})$, olivine $(\mathrm{Mg})$, orthoclase $(\mathrm{K})$, spessartine $(\mathrm{Mn})$, thorite $(\mathrm{Th})$, villiaumite $(\mathrm{F})$, witherite $(\mathrm{Ba})$, metallic $\mathrm{Pb}, \mathrm{REE}$-bearing glasses ( $\mathrm{Pr}, \mathrm{Nd}, \mathrm{Sm}$ (Drake and Weill, 1972)), synthetic $\mathrm{SrTiO}_{3}(\mathrm{Sr}$, Ti), $\mathrm{ZrO}_{2}, \mathrm{UO}_{2}, \mathrm{LaVO}_{4}(\mathrm{La})$ and $\mathrm{Nb}_{2} \mathrm{O}_{5}(\mathrm{Nb})$. The WDS analyses (Tables 2 and 3 , analyses $1-3$ ) show that: (1) REE, Ti, Nb, Ca, Sr, Th and, in loparite, also $\mathrm{Na}$, are the major elements; (2) Fe, $\mathrm{Ta}, \mathrm{Sm}, \mathrm{U}$ and $\mathrm{F}$ are present in low concentrations $(<0.40$ wt. $\%$ element), $\mathrm{Mn}$ and $\mathrm{Zr}$ contents are near or below detection limits $(<0.06$ wt.\% element); (3) $\mathrm{Mg}, \mathrm{K}, \mathrm{Ba}$ and $\mathrm{Pb}$ are not present in detectable quantities; (4) lanthanides are represented by light $R E E$ which are strongly dominated by $\mathrm{Ce}(\mathrm{Ce}>\mathrm{La}>\mathrm{Nd}>\mathrm{Pr}>\mathrm{Sm})$.

On the basis of these data and using wellcharacterized mineral and synthetic standards that had been previously employed in a number of studies on naturally-occurring perovskite, loparite and associated REE-bearing phases (Mitchell and Chakhmouradian, 1996, 1998a; Chakhmouradian and Mitchell, 1997, 1998a), a representative collection of loparite and 'metaloparite' from Burpala was examined by X-ray energy-dispersion spectrometry (EDS) using a Hitachi 570 SEM equipped with a LINK ISIS analytical system incorporating a Super ATW Light Element Detector (133 eV FWHM Mn- K). Raw EDS spectra were acquired for $180 \mathrm{~s}$ (live time) with an accelerating voltage of $20 \mathrm{kV}$ and beam current of $0.86 \mathrm{nA}$. The spectra were processed with the LINK ISIS-SEMQUANT software, with full ZAF corrections. The following standards were employed for the determination of mineral compositions: Khibina loparite $(\mathrm{Na}, \mathrm{La}, \mathrm{Ce}, \mathrm{Pr}$, $\mathrm{Nd}$ ), Magnet Cove perovskite ( $\mathrm{Ca}, \mathrm{Ti}, \mathrm{Fe})$, synthetic $\mathrm{SrTiO}_{3}(\mathrm{Sr})$, and metallic $\mathrm{Ta}$ and $\mathrm{Th}$. 


\section{A. R. CHAKHMOURADIAN ETAL.}

TABLE 2. Representative compositions of loparite from Burpala

\begin{tabular}{|c|c|c|c|c|c|c|c|c|c|}
\hline Wt.\% & 1 & 2 & 3 & 4 & 5 & 6 & 7 & 8 & 9 \\
\hline $\mathrm{Na}_{2} \mathrm{O}$ & 7.95 & 7.65 & 7.85 & 8.02 & 7.56 & 7.41 & 7.79 & 7.32 & 8.05 \\
\hline $\mathrm{CaO}$ & 1.42 & 1.16 & 1.05 & 0.94 & 1.43 & 1.23 & 0.81 & 1.46 & 0.63 \\
\hline $\mathrm{SrO}$ & 2.28 & 1.65 & 2.25 & 2.44 & 1.72 & 2.61 & 1.70 & 1.80 & 1.41 \\
\hline $\mathrm{La}_{2} \mathrm{O}_{3}$ & 12.61 & 13.84 & 13.16 & 13.55 & 12.34 & 11.89 & 13.44 & 13.39 & 12.54 \\
\hline $\mathrm{Ce}_{2} \mathrm{O}_{3}$ & 20.77 & 21.93 & 20.71 & 21.40 & 21.54 & 19.92 & 22.03 & 21.23 & 20.35 \\
\hline $\mathrm{Pr}_{2} \mathrm{O}_{3}$ & 1.44 & 1.38 & 1.47 & 1.34 & 2.03 & 2.27 & 2.31 & 2.52 & 1.50 \\
\hline $\mathrm{Nd}_{2} \mathrm{O}_{3}$ & 3.67 & 3.15 & 3.66 & 3.38 & 3.46 & 3.43 & 3.19 & 3.61 & 4.30 \\
\hline $\mathrm{Sm}_{2} \mathrm{O}_{3}$ & 0.18 & 0.01 & 0.06 & n.a & n.a & n.a & n.a & n.a & n.a \\
\hline $\mathrm{ThO}_{2}$ & 3.82 & 2.45 & 3.00 & 2.07 & 2.85 & 3.07 & 2.52 & 2.59 & 5.21 \\
\hline $\mathrm{UO}_{2}$ & 0.34 & 0.11 & 0.26 & n.a & n.a & n.a & n.a & n.a & n.a \\
\hline $\mathrm{TiO}_{2}$ & 42.90 & 42.78 & 42.32 & 41.88 & 41.45 & 41.35 & 42.31 & 42.41 & 41.87 \\
\hline $\mathrm{Fe}_{2} \mathrm{O}_{3}{ }^{\mathrm{a}}$ & 0.21 & 0.12 & 0.10 & 0.31 & 0.38 & 0.23 & 0.43 & 0.41 & 0.56 \\
\hline $\mathrm{Nb}_{2} \mathrm{O}_{5}$ & 3.49 & 4.09 & 4.51 & 4.72 & 4.05 & 4.11 & 3.46 & 3.26 & 4.37 \\
\hline $\mathrm{Ta}_{2} \mathrm{O}_{5}$ & n.d & 0.51 & 0.16 & 0.37 & 0.30 & 0.63 & 0.32 & 0.25 & n.d \\
\hline $\mathrm{F}$ & 0.09 & n.d & 0.08 & n.a & n.a & n.a & n.a & n.a & n.a \\
\hline Total & $101.13^{\mathrm{b}}$ & 100.80 & $100.61^{\mathrm{c}}$ & 100.42 & 99.11 & 98.15 & 100.30 & 100.25 & 100.79 \\
\hline \multicolumn{10}{|c|}{$\begin{array}{l}\text { Structural formulae }(\mathrm{O}+\mathrm{F}=3) \\
A \text {-cations }\end{array}$} \\
\hline $\mathrm{Na}$ & 0.453 & 0.435 & 0.447 & 0.458 & 0.438 & 0.433 & 0.447 & 0.420 & 0.462 \\
\hline $\mathrm{Ca}$ & 0.045 & 0.036 & 0.033 & 0.030 & 0.046 & 0.040 & 0.026 & 0.046 & 0.020 \\
\hline $\mathrm{Sr}$ & 0.039 & 0.028 & 0.038 & 0.042 & 0.030 & 0.046 & 0.029 & 0.031 & 0.024 \\
\hline $\mathrm{La}$ & 0.137 & 0.150 & 0.143 & 0.147 & 0.136 & 0.132 & 0.147 & 0.146 & 0.137 \\
\hline $\mathrm{Ce}$ & 0.219 & 0.235 & 0.223 & 0.231 & 0.236 & 0.220 & 0.239 & 0.230 & 0.220 \\
\hline $\operatorname{Pr}$ & 0.015 & 0.015 & 0.016 & 0.014 & 0.022 & 0.025 & 0.025 & 0.027 & 0.016 \\
\hline $\mathrm{Nd}$ & 0.038 & 0.033 & 0.038 & 0.036 & 0.037 & 0.037 & 0.034 & 0.038 & 0.045 \\
\hline $\mathrm{Sm}$ & 0.002 & - & 0.001 & - & - & - & - & - & - \\
\hline $\mathrm{Th}$ & 0.026 & 0.016 & 0.020 & 0.014 & 0.019 & 0.021 & 0.017 & 0.017 & 0.035 \\
\hline U & 0.002 & 0.001 & 0.002 & - & - & - & - & - & - \\
\hline$\Sigma$ & 0.947 & 0.949 & 0.961 & 0.971 & 0.964 & 0.953 & 0.961 & 0.956 & 0.959 \\
\hline \multicolumn{10}{|l|}{$B$-cations } \\
\hline $\mathrm{Ti}$ & 0.947 & 0.943 & 0.936 & 0.928 & 0.932 & 0.937 & 0.942 & 0.944 & 0.931 \\
\hline $\mathrm{Fe}$ & 0.005 & 0.003 & 0.002 & 0.007 & 0.009 & 0.005 & 0.010 & 0.009 & 0.012 \\
\hline $\mathrm{Nb}$ & 0.046 & 0.054 & 0.060 & 0.063 & 0.055 & 0.056 & 0.046 & 0.044 & 0.058 \\
\hline $\mathrm{Ta}$ & - & 0.004 & 0.001 & 0.003 & 0.002 & 0.005 & 0.003 & 0.002 & 0.000 \\
\hline$\Sigma$ & 0.998 & 1.004 & 0.999 & 1.000 & 0.998 & 1.004 & 1.001 & 0.999 & 1.002 \\
\hline Anions & & & & & & & & & \\
\hline $\mathrm{O}^{2-}$ & 2.992 & 3.000 & 2.993 & 3.000 & 3.000 & 3.000 & 3.000 & 3.000 & 3.000 \\
\hline $\mathrm{F}^{-}$ & 0.008 & - & 0.007 & - & - & - & - & - & - \\
\hline \multicolumn{10}{|c|}{ Mol. \% end-members } \\
\hline $\mathrm{NaCeTi}_{2} \mathrm{O}_{6}$ & 81.40 & 78.21 & 78.86 & 80.23 & 77.98 & 77.39 & 81.80 & 77.32 & 81.07 \\
\hline $\mathrm{NaNbO}_{3}$ & 4.60 & 6.02 & 6.23 & 6.38 & 5.57 & 5.75 & 4.73 & 4.48 & 5.87 \\
\hline $\mathrm{ThTi}_{2} \mathrm{O}_{6}$ & 5.20 & 3.32 & 4.08 & 2.82 & 3.94 & 4.32 & 3.46 & 3.58 & 7.05 \\
\hline $\mathrm{CaTiO}_{3}$ & 4.50 & 3.74 & 3.37 & 3.01 & 4.66 & 4.08 & 2.62 & 4.75 & 2.01 \\
\hline $\mathrm{SrTiO}_{3}$ & 3.90 & 2.90 & 3.88 & 4.23 & 3.03 & 4.68 & 2.98 & 3.17 & 2.43 \\
\hline $\mathrm{Ce}_{2} \mathrm{Ti}_{2} \mathrm{O}_{7}$ & 0.40 & 5.81 & 3.58 & 3.33 & 4.83 & 3.78 & 4.42 & 6.70 & 1.57 \\
\hline
\end{tabular}

Compositions: 1-8: (microcline-) riebeckite-albite metasomatites; 9: fenite.

1-3 WDS, 4-9 EDS analyses.

a total $\mathrm{Fe}$ expressed as $\mathrm{Fe}_{2} \mathrm{O}_{3}$

$\mathrm{b}$ analysis total excluding 0.04 wt. $\%-\mathrm{O} \equiv \mathrm{F}_{2}$

${ }^{\mathrm{c}}$ analysis total excluding 0.03 wt. $\%-\mathrm{O} \equiv \mathrm{F}_{2}$

n.a. $=$ not analysed, n.d. $=$ not detected. 
LOPARITE AND 'METALOPARITE’ FROM RUSSIA

TABLE 3. Representative compositions of 'metaloparite' from Burpala

\begin{tabular}{lccccccccccc}
\hline $\mathrm{Wt} . \%$ & 1 & 2 & 3 & 4 & 5 & 6 & 7 & 8 & 9 & 10 & 11 \\
\hline $\mathrm{Na}_{2} \mathrm{O}$ & 0.03 & n.d & n.d & n.d & n.d & n.d & n.d & n.d & n.d & n.d & n.d \\
$\mathrm{CaO}$ & 2.26 & 2.06 & 0.53 & 1.01 & 2.02 & 1.80 & 0.27 & 1.60 & 0.28 & 0.36 & 0.22 \\
$\mathrm{SrO}$ & 0.04 & 0.30 & 0.79 & 1.30 & 0.58 & 0.68 & 0.53 & 1.72 & 0.43 & 0.66 & 0.45 \\
$\mathrm{La}_{2} \mathrm{O}_{3}$ & 12.33 & 13.61 & 15.17 & 14.80 & 12.96 & 12.65 & 14.85 & 13.13 & 11.20 & 13.89 & 13.88 \\
$\mathrm{Ce}_{2} \mathrm{O}_{3}$ & 19.14 & 20.44 & 22.77 & 23.36 & 22.89 & 21.55 & 22.59 & 21.31 & 19.81 & 21.72 & 22.92 \\
$\mathrm{Pr}_{2} \mathrm{O}_{3}$ & 1.51 & 1.67 & 1.60 & 1.09 & 1.59 & 2.03 & 2.06 & 1.09 & 2.40 & 2.65 & 1.77 \\
$\mathrm{Nd}_{2} \mathrm{O}_{3}$ & 4.05 & 4.00 & 3.40 & 3.05 & 4.00 & 4.79 & 3.57 & 4.32 & 5.82 & 5.32 & 4.50 \\
$\mathrm{Sm}_{2} \mathrm{O}_{3}$ & 0.18 & 0.11 & 0.11 & n.a & n.a & n.a & n.a & n.a & n.a & n.a & n.a \\
$\mathrm{ThO}_{2}$ & 6.02 & 4.82 & 2.85 & 1.83 & 3.59 & 3.33 & 4.26 & 2.97 & 11.01 & 5.25 & 5.20 \\
$\mathrm{UO}_{2}$ & 0.48 & 0.41 & 0.16 & n.a & n.a & n.a & n.a & n.a & n.a & n.a & n.a \\
$\mathrm{TiO}_{2}$ & 45.61 & 45.87 & 44.25 & 46.36 & 44.13 & 44.70 & 43.01 & 45.08 & 41.01 & 42.79 & 44.38 \\
$\mathrm{Fe}_{2} \mathrm{O}_{3}{ }^{\mathrm{a}}$ & 0.15 & 0.23 & 0.26 & 0.24 & 0.36 & 0.20 & 0.26 & 0.38 & n.d & 0.49 & 0.16 \\
$\mathrm{Nb}_{2} \mathrm{O}_{5}$ & 2.83 & 2.97 & 4.06 & 3.80 & 3.85 & 4.54 & 3.59 & 3.39 & 3.11 & 2.14 & 3.11 \\
$\mathrm{Ta}_{2} \mathrm{O}_{5}$ & 0.16 & 0.14 & 0.35 & 0.37 & 0.52 & 0.72 & 0.48 & n.d & 0.26 & 0.81 & 0.38 \\
$\mathrm{~F}$ & 0.10 & 0.24 & 0.30 & n.a & n.a & n.a & n.a & n.a & n.a & n.a & n.a \\
$\mathrm{Total}$ & 94.84 & 96.74 & 96.49 & 97.21 & 96.49 & 97.09 & 95.47 & 94.99 & 95.33 & 96.08 & 96.97
\end{tabular}

Structural formulae $(\Sigma B$-cations $=2)$

$A$-cations

$\begin{array}{lcccccccccccc}\mathrm{Na} & 0.003 & - & - & - & - & - & - & - & - & - & - \\ \mathrm{Ca} & 0.136 & 0.122 & 0.032 & 0.059 & 0.122 & 0.107 & 0.017 & 0.096 & 0.019 & 0.023 & 0.013 \\ \mathrm{Sr} & 0.001 & 0.010 & 0.026 & 0.041 & 0.019 & 0.022 & 0.018 & 0.056 & 0.015 & 0.023 & 0.015 \\ \mathrm{La} & 0.254 & 0.278 & 0.316 & 0.296 & 0.271 & 0.259 & 0.319 & 0.271 & 0.256 & 0.304 & 0.293 \\ \mathrm{Ce} & 0.392 & 0.415 & 0.471 & 0.464 & 0.474 & 0.438 & 0.482 & 0.437 & 0.449 & 0.471 & 0.480 \\ \mathrm{Pr} & 0.031 & 0.034 & 0.033 & 0.022 & 0.033 & 0.041 & 0.044 & 0.022 & 0.054 & 0.057 & 0.037 \\ \mathrm{Nd} & 0.081 & 0.079 & 0.069 & 0.059 & 0.081 & 0.095 & 0.074 & 0.086 & 0.129 & 0.113 & 0.092 \\ \mathrm{Sm} & 0.001 & 0.002 & 0.002 & - & - & - & - & - & - & - & - \\ \mathrm{Th} & 0.077 & 0.061 & 0.037 & 0.023 & 0.046 & 0.042 & 0.057 & 0.038 & 0.155 & 0.071 & 0.068 \\ \mathrm{U} & 0.006 & 0.005 & 0.002 & - & - & - & - & - & - & - & - \\ \Sigma & 0.984 & 1.006 & 0.988 & 0.963 & 1.046 & 1.005 & 1.011 & 1.006 & 1.076 & 1.062 & 0.997 \\ B-\text { cations } & & & & & & & & & & & \\ \mathrm{Ti} & 1.919 & 1.914 & 1.880 & 1.892 & 1.878 & 1.867 & 1.886 & 1.898 & 1.909 & 1.908 & 1.907 \\ \mathrm{Fe} & 0.006 & 0.010 & 0.011 & 0.010 & 0.015 & 0.008 & 0.011 & 0.016 & - & 0.022 & 0.007 \\ \mathrm{Nb} & 0.072 & 0.074 & 0.104 & 0.093 & 0.099 & 0.114 & 0.095 & 0.086 & 0.087 & 0.057 & 0.080 \\ \mathrm{Ta} & 0.002 & 0.002 & 0.005 & 0.005 & 0.008 & 0.011 & 0.008 & - & 0.004 & 0.013 & 0.006 \\ \Sigma & 2.000 & 2.000 & 2.000 & 2.000 & 2.000 & 2.000 & 2.000 & 2.000 & 2.000 & 2.000 & 2.000 \\ \mathrm{Anions} & & & & & & & & & & & \\ \mathrm{O}^{2-} & 4.960 & 5.020 & 5.041 & 4.901 & 5.135 & 5.043 & 5.147 & 4.975 & 5.442 & 5.258 & 5.109 \\ \mathrm{~F}^{1-} & 0.017 & 0.042 & 0.054 & - & - & - & - & - & - & - \\ \mathrm{e}(\mathrm{OH})^{1-} & 1.023 & 0.938 & 0.904 & 1.099 & 0.865 & 0.957 & 0.853 & 1.025 & 0.558 & 0.742 & 0.891 \\ \mathrm{H}_{2} \mathrm{O}^{\mathrm{f}} & 0.456 & 0.135 & 0.218 & - & 0.230 & 0.080 & 0.455 & 0.424 & 0.686 & 0.405 & 0.132 \\ & & & & & & & & & & & \end{array}$

Compositions: 1-7: (microcline-) riebeckite-albite metasomatites; 8: albitite; 9 \& 10: (microcline-) aegirinealbite metasomatites, 11: aegirinite.

1-3: WDS; 4-11: EDS analyses.

a total $\mathrm{Fe}$ expressed as $\mathrm{Fe}_{2} \mathrm{O}_{3}$

b analysis total excluding 0.04 wt. $\%-\mathrm{O} \equiv \mathrm{F}_{2}$

c analysis total excluding $0.10 \mathrm{wt} \%-\mathrm{O} \equiv \mathrm{F}_{2}$

$\mathrm{d}$ analysis total excluding 0.12 wt. $\%-\mathrm{O} \equiv \mathrm{F}_{2}$

E calculated from stoichiometry

$\mathrm{f}$ calculated from the difference between analysis totals and $100 \%$ after subtraction of hydroxyl water content n.a. $=$ not analysed; n.d. $=$ not detected . 


\section{A. R. CHAKHMOURADIAN ETAL.}

A multi-element standard for REE (loparite) was used, as experience has shown that this gives more accurate data than single-REE standards when using EDS spectrum-stripping techniques. However, peak profiles used for the analytical $\mathrm{X}$-ray lines were obtained on single $R E E$ fluoride standards. The quantitative data obtained by EDS are in a good agreement with those obtained by wavelength-dispersion spectrometry (WDS) (cf. analyses 3 and 4 in Table 2).

Samples of loparite and 'metaloparite' from different parageneses were found to show very little intra- and intergranular variation with respect to the major and minor components. Correspondingly, we selected one representative sample of loparite and two of 'metaloparite' for X-ray diffraction (XRD) studies. The samples were crushed and hand-picked using a binocular microscope in order to avoid impurities of aegirine, albite and other silicates commonly present as poikilitic inclusions. For comparison, we also examined several representative samples of loparite from other well-characterized occurrences, including the Lovozero and Khibina alkaline complexes of the Kola Peninsula (Mitchell and Chakhmouradian, 1996; Chakhmouradian and Mitchell, 1998a).

$\mathrm{X}$-ray diffraction powder patterns $(\mathrm{Cu}$ radiation) of loparite were obtained with a Philips 3710 and a DRON-2.0 diffractometers. The Philips 3710 diffractometer was operated at $40 \mathrm{kV}$ and $30 \mathrm{~mA}$ in the step-scanning mode. For 'metaloparite', a Philips Debye-Scherer type camera with a diameter of $114.6 \mathrm{~mm}$ was employed. The DRON-2.0 diffractometer was operated at $35 \mathrm{kV}$ and $20 \mathrm{~mA}$ in the scanning mode at a goniometer rotation rate of $0.5 \% \mathrm{~min}$. Metallic Ge was used as an internal standard.

Infrared (IR) transmission spectra of 'metaloparite' $\left(400-4000 \mathrm{~cm}^{-1}\right)$ were recorded from a powder with a Specord 75 IR spectrophotometer, and from a thin crystal fragment on a FTIR IFS66 spectrometer equipped with a microscope. The powder sample was cleaned of inclusions, and pressed into $\mathrm{KBr}$ pellets at $70 \mathrm{kbar}$ pressure. The spectrum of the fragment was averaged from 256 scans using a reference spectrum to account for water vapour apparently present in the spectrometer. The IR spectra obtained are very similar, and below we discuss only the powder spectrum as it has better resolution, compared to the spectrum from the crystal fragment.

In this work, we also studied a synthetic analogue of loparite prepared using the ceramic technique. The compound $\mathrm{NaCe}^{3+} \mathrm{Ti}_{2} \mathrm{O}_{6}$ was synthesized from $\mathrm{Na}_{2} \mathrm{CO}_{3}, \mathrm{TiO}_{2}$ and $\mathrm{CeO}_{2}$ (high purity grade), using charcoal as a reducing reagent:

$$
2 \mathrm{Na}_{2} \mathrm{CO}_{3}+4 \mathrm{CeO}_{2}+8 \mathrm{TiO}_{2}+\underset{4 \mathrm{NaCeTi}_{2} \mathrm{O}_{6}+3 \mathrm{CO}_{2}}{3 \mathrm{C}=}
$$

The reagents were dried at $120^{\circ} \mathrm{C}$, and then mixed in stoichiometric amounts and ground in an agate mortar. The mixture was heated in air to $1000^{\circ} \mathrm{C}$ for $24 \mathrm{~h}$ initially to avoid the loss of $\mathrm{Na}$. After regrinding, the sample was heated in air to $1200^{\circ} \mathrm{C}$ for $48 \mathrm{~h}$, and then rapidly cooled to room temperature.

The synthesis product is a black powder with the size of individual crystals $<20 \mu \mathrm{m}$. The EDS and XRD examination shows the presence of minor $\mathrm{CeO}_{2}$ plus $\mathrm{TiO}_{2}$ (rutile) associated with a perovskite-type phase. The composition of the latter compound was determined using the same methods and standards as described above for naturally-occurring phases, and found to be within analytical error of the ideal composition $\mathrm{NaCeTi}_{2} \mathrm{O}_{6}$. An XRD powder pattern $(\mathrm{Cu}$ radiation) of the synthesized $\mathrm{NaCeTi}_{2} \mathrm{O}_{6}$ was obtained with a Philips 3710 diffractometer in the step-scanning mode $\left(\Delta 2 \theta\right.$ step $0.02^{\circ}$; time per step $2 \mathrm{~s})$ in the $2 \theta$ range $10-145^{\circ}$. The pattern was subsequently analysed by the Rietveld method using the FULLPROF software package (Rodriguez-Carvajal, 1990).

\section{Composition}

Loparite from alkaline rocks of the Burpala complex is relatively simple in composition, and approaches the ideal formula $\mathrm{NaREETi} \mathrm{O}_{6}$. Regardless of the host rock, this loparite is poor in $\mathrm{CaO}(0.6-1.6$ wt.\%), $\mathrm{SrO}(1.2-2.4$ wt.\%) and $\mathrm{Nb}_{2} \mathrm{O}_{5}$ (2.4-5.4 wt.\%) (Table 2). In most parageneses, loparite is significantly enriched in $\mathrm{ThO}_{2}$ (up to 5.7 wt.\% in fenite). No obvious correlation between different minor elements is observed. In back-scattered electron images (BSE), loparite appears compositionally homogeneous and devoid of zonation. However, some crystals do show some variation in major and minor elements, as determined from several analyses obtained at different points within the crystal. Compositional variation between the different host rocks is very weak, and is similar to the intragranular variation in loparite from individual parageneses. Representative compositions of the Burpala loparite (Table 2) were 
a)
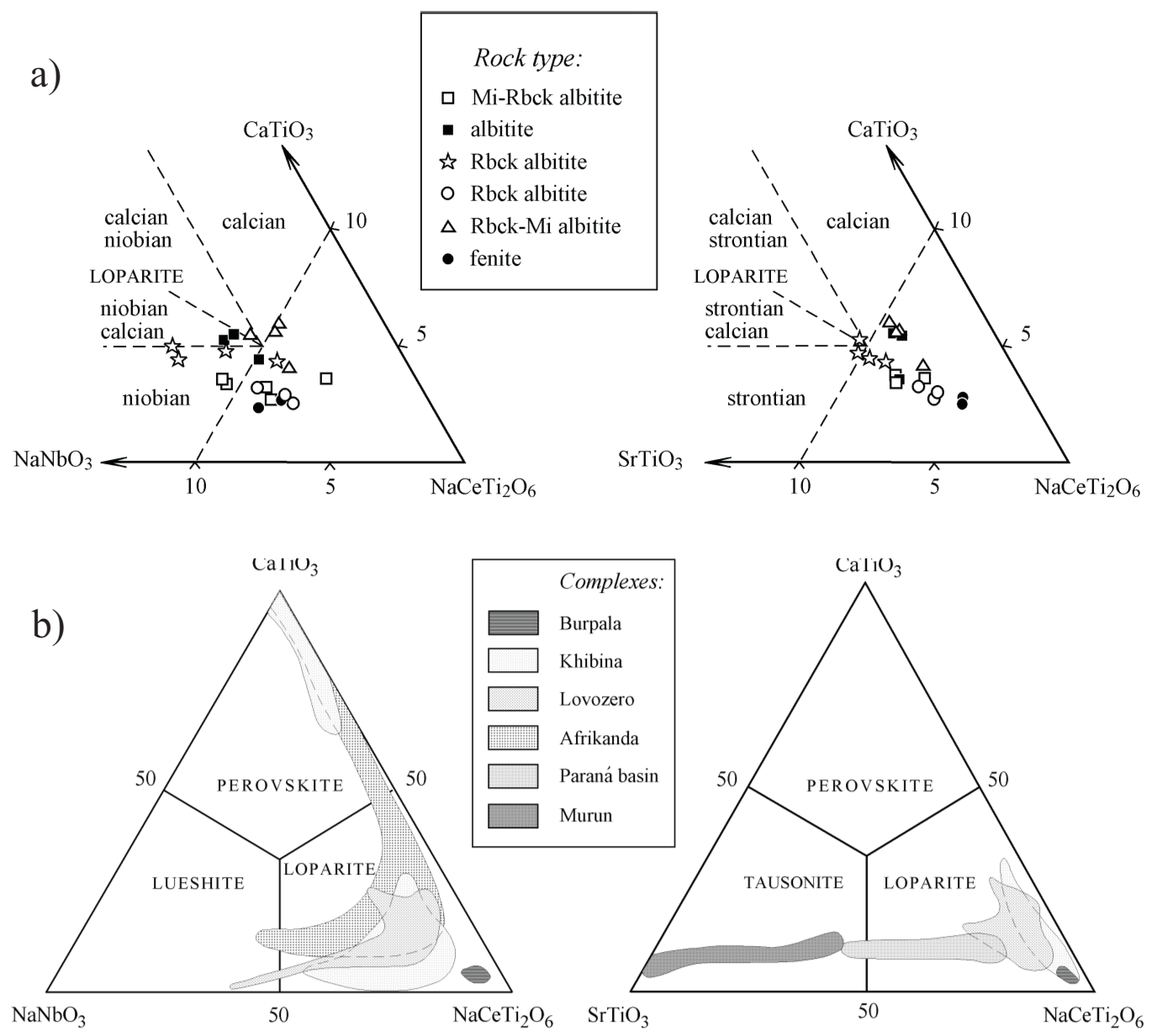

FIG. 1. Compositional variation of loparite from Burpala and other alkaline occurrences. Note that the $\mathrm{NaCeTi}_{2} \mathrm{O}_{6}$ end-member accounts for all the LREE dominated by Ce. (a) compositional variation of loparite from albite metasomatic rocks of the Burpala complex; $(b)$ compositional variation of loparite and related perovskite-group minerals from nepheline-syenite, carbonatite and ultrapotassic syenite complexes worldwide.

recalculated into end-member components following the suggestions of Mitchell (1996) and Mitchell and Chakhmouradian (1998b). Loparite(Ce) $\left(\mathrm{NaCeTi}_{2} \mathrm{O}_{6}\right)$ is the predominant component in this loparite, and far outweighs other components, including perovskite $\left(\mathrm{CaTiO}_{3}\right)$, tausonite $\left(\mathrm{SrTiO}_{3}\right)$, lueshite $\left(\mathrm{NaNbO}_{3}\right)$ and $\mathrm{ThTi}_{2} \mathrm{O}_{6}$ (Table 2, Fig. 1a).

Compared to loparite from Burpala, that from other alkaline complexes is typically richer in minor components, i.e. $\mathrm{CaTiO}_{3}, \mathrm{SrTiO}_{3}$ and $\mathrm{NaNbO}_{3}$. In the nepheline-syenite intrusions of the Kola peninsula (Lovozero and Khibina), and carbonatite complexes (Afrikanda and Vuorijarvi at Kola, Schryburt Lake in Ontario, Gardiner in East Greenland), loparite is typically enriched in $\mathrm{CaTiO}_{3}$ and/or $\mathrm{NaNbO}_{3}$ (Platt, 1994; Mitchell and Chakhmouradian, 1996; Chakhmouradian and Mitchell, 1997; 1998a; Campbell et al., 1997). This loparite is generally poor in $\mathrm{SrTiO}_{3}(<16$ mol.\%: Mitchell and Chakhmouradian, 1996). High $\mathrm{SrTiO}_{3}$ contents are found in loparite from rheomorphic fenites of the Paraná Basin complexes (Haggerty and Mariano, 1983; 


\section{A. R. CHAKHMOURADIAN ETAL.}

Mitchell, 1996), and peralkaline pegmatites at Gordon Butte and Pegmatite Peak in Montana (Mitchell and Chakhmouradian, submitted). Loparite from these occurrences is generally poor in $\mathrm{CaTiO}_{3}$, and shows a significant variation in $\mathrm{NaNbO}_{3}$. The enrichment in Th observed in the present study is a relatively rare compositional feature for loparite. In most occurrences, the $\mathrm{ThO}_{2}$ content in this mineral does not exceed 1.5 wt.\%. Extremely Th-rich compositions (up to 18.4 wt.\% $\mathrm{ThO}_{2}$ ) have been described from the Khibina complex (Mitchell and Chakhmouradian, 1998b). The data for loparite from different alkaline-rock occurrences are compared in Fig. $1 b$.

'Metaloparite' is a homogeneous phase, not an aggregate of several minerals. Compositionally, it is a $R E E$-Ti oxide-hydroxide with minor $\mathrm{Ca}, \mathrm{Nb}$, Th and negligible Sr, Fe and Ta (Table 3). Our data confirm the previously published studies (Gerasimovskii, 1941; Saltykova, 1959; Lumpkin et al., 1997) that 'metaloparite' differs from loparite in containing significant $\mathrm{H}_{2} \mathrm{O}$, but no alkalies. In addition, the analyses of loparite and 'metaloparite' occurring in the same paragenesis, show that the latter mineral is typically somewhat richer in $\mathrm{Ca}$ and poorer in $\mathrm{Sr}$ (cf. analyses 1, 2, $4-6$ in Tables 2 and 3). Other compositional features observed in loparite, including the predominance of $\mathrm{Ce}$ over $\mathrm{La}$ and other LREE, and relative distribution of the $B$-site cations, are preserved in 'metaloparite'.

Assuming that in most Ti-, Nb- and Ta-based oxides, the $A$-site cations and anions can be strongly affected by deuteric and hypergene alteration, whereas the $B$-site cations comprising a rigid structural motif, remain relatively unaffected, structural formulae of these minerals can be calculated on the basis of a fixed number of the $B$-site cations. Recalculation of 'metaloparite' analyses using this approach gives the empirical formula $A B_{2} \mathrm{O}_{6-x}(\mathrm{OH})_{x} \cdot \mathrm{nH}_{2} \mathrm{O}(A=R E E, \mathrm{Ca}, \mathrm{Sr}$, $\mathrm{Th} ; B=\mathrm{Ti}, \mathrm{Nb}, \mathrm{Ta}, \mathrm{Fe} ; x=0.6-1.1 ; \mathrm{n}=0.1-0.7)$. A very similar formula has been deduced for the type 'metaloparite' from wet-chemical analysis (Gerasimovskii, 1941). Potentially, a large number of minerals, including lucasite-(Ce), and members of the aeschynite, pyrochlore and perovskite groups, may have this type of formula. The compositions of 'metaloparite' and those of other naturally-occurring or synthetic $A B_{2} \mathrm{O}_{6}$-type compounds are compared in Fig. 2 (see references therein). The weight percentages of major components rather than atomic percen- tages are used in this diagram, because in most early studies, no distinction was made between the individual REE. Note however, that we have chosen only those compositions in which the lanthanides are strongly dominated by the LREE. From Fig. 2, it is evident that 'metaloparite' from Burpala is strongly depleted in $\mathrm{Nb}$, compared to the aeschynite- and pyrochlore-group REE oxides. The compositions of 'metaloparite' from the other occurrences plot near the Burpala field, but show some enrichment in $\mathrm{Nb}$. The best correspondence is observed between the compositions of 'metaloparite', lucasite-(Ce) (Nickel et al., 1987) and the synthetic compound $\mathrm{CeTi}_{2} \mathrm{O}_{5.6}$ (Leonov et al., 1966).

Lucasite-(Ce) has the simplified formula $\mathrm{CeTi}_{2} \mathrm{O}_{5} \mathrm{OH}$, and crystallizes with monoclinic symmetry. The structure of this mineral is built of edge-sharing $\mathrm{TiO}_{6}$ octahedra arranged in a 'honeycomb' fashion within (001) planes. The pairs of $\mathrm{TiO}_{6}$-layers alternate with single layers of the edge-sharing $\mathrm{CeO}_{8}$ polyhedra (Nickel et al., 1987). The compound $\mathrm{CeTi}_{2} \mathrm{O}_{5.6}$ has an unknown structure, and gives an XRD pattern showing very little resemblance to that of lucasite-(Ce).

\section{X-ray diffractometry}

Loparite from Burpala gives an XRD powder pattern similar to those of loparite from other occurrences. The patterns show several strong diffraction lines which can be indexed on the primitive cubic cell $(P m \overline{3} m)$, together with a few low-intensity peaks indicating lower than cubic symmetry. In most previous works, only cubic indexing is given for the XRD patterns of loparite, and cell dimensions are reported. However, the pseudocubic true symmetry of the mineral has been established already in earlier studies, based on the anisotropic optical character of loparite and single-crystal X-ray photographs. Commonly present polysynthetic and interpenetration twinning complicate an examination of this mineral by single-crystal methods. Transmission electron microscopy studies of naturally-occurring loparite from Lovozero suggest orthorhombic symmetry and the space group Pnma (Hu et al., 1992).

Synthetic analogues of loparite have been described previously in a number of studies. In most of these works, the perovskite-type compounds $\mathrm{NaREETi}_{2} \mathrm{O}_{6}(R E E=\mathrm{La}, \mathrm{Ce}, \mathrm{Pr}$, $\mathrm{Nd})$ are claimed to have the undistorted cubic structure with the space group $P m \overline{3} m$ (Belous et al., 1985; Kirsanov and Bazuev, 1988; Kirsanov 


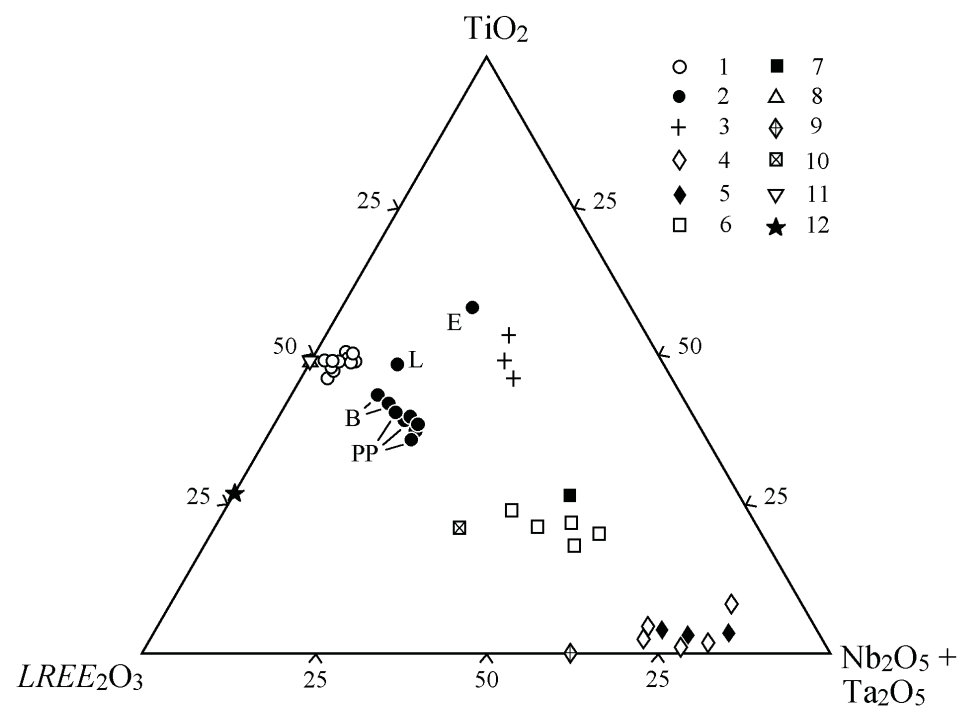

FIG. 2. Compositions of 'metaloparite' from Burpala and other $A B_{2} \mathrm{O}_{6}$-type oxides of REE. (1) 'metaloparite', Burpala (this work); (2) 'metaloparite', Bratthagen (B): Lumpkin et al. (1997), Lovozero (L): Gerasimovskii (1941), Enisei Ridge (E): Saltykova (1959), Pegmatite Peak (PP): Chakhmouradian and Mitchell (unpubl. data); (3) 'ceriobetafite', Khibina (Mitchell and Chakhmouradian, 1998a); (4-5) ceriopyrochlore: 4 Enisei Ridge (Lapin and Kulikova, 1989), 5 Lueshe (Wall et al., 1996); (6-7) nioboaeschynite-(Ce): 6 Ural Mts. (Lebedeva and Nedosekova, 1993), 7 Alaska (Rosenblum and Mosier, 1975); (8) lucasite-(Ce), Australia (Nickel et al., 1987); (9) ideal ceriopyrochlore $\mathrm{CeNb}_{2} \mathrm{O}_{6}(\mathrm{OH})$; (10) ideal aeschynite-(Ce) $\mathrm{CeTiNbO}_{6}$; (11) $\mathrm{CeTi}_{2} \mathrm{O}_{5.6}$; (12) $\mathrm{Ce}_{0.66} \mathrm{TiO}_{3}$.

et al., 1988). On the basis of XRD patterns and IR spectra, Kaleveld et al. (1973) suggest that $\mathrm{NaLaTi}_{2} \mathrm{O}_{6}$ has a cubic structure with ordered arrangement of $\mathrm{Na}$ and $\mathrm{La}$ at the $A$-sites. Recently, Sun et al. (1997) and Shan et al. (1998) have proposed the orthorhombic symmetry (space

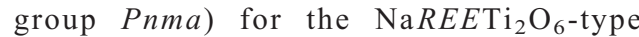
compounds with REE smaller than $\mathrm{Ce}^{3+}$, i.e. $\mathrm{Pr}$, $\mathrm{Nd}, \mathrm{Sm}-\mathrm{Lu}$.

Importantly, Kaleveld et al. (1973) did not list the $d$-spacings for $\mathrm{NaLaTi}_{2} \mathrm{O}_{6}$ examined in their work, and the diffraction lines attributed by these authors to superlattice ordering peaks, may actually correspond to the two strongest peaks of $\mathrm{Na}_{2} \mathrm{Ti}_{6} \mathrm{O}_{13}$ (7.5 and $3.6 \AA$ ), a typical by-product of loparite synthesis. Another possible explanation of the interpretation given by Kaleveld et al. (1973), is a significant loss of $\mathrm{Na}$ during their synthesis experiment. It has been previously established that the loss of $\mathrm{Na}$ and creation of vacancies in the structure of $\mathrm{NaREETi}{ }_{2} \mathrm{O}_{6}(R E E=$ $\mathrm{La}, \mathrm{Ce}, \mathrm{Pr}, \mathrm{Nd}$ ), leads to cation ordering at the $A$-site, and thus, appearance of superlattice peaks on the XRD patterns (Kirsanov and Bazuev, 1988; Kirsanov et al., 1988).
The compound $\mathrm{NaCe}^{3+} \mathrm{Ti}_{2} \mathrm{O}_{6}$ synthesized in the present study, gives an XRD powder pattern similar to that of naturally-occurring loparite. The pattern can be indexed in either the tetragonal I4/ $m \mathrm{~cm}$ or orthorhombic Pnma space groups. The diffraction lines at 3.44 and $1.68 \AA$ (111 and 311 in orthorhombic indexing) which could be used to distinguish between the two space groups, are very low in intensity. Consequently, the XRD pattern of $\mathrm{NaCeTi}_{2} \mathrm{O}_{6}$ was refined using both possible structural models. In the initial structural models, we used unit-cell parameters calculated from the pattern using the PARAM software (Department of Crystallography, St. Petersburg State University), and set all refinable atomic coordinates to their ideal values (Woodward, 1997). The refinement in the space group Pnma gave a significantly better fit between the observed and calculated patterns, than the refinement using the tetragonal structural model (Table 4, Fig. 3). Thus we suggest that $\mathrm{NaCeTi}_{2} \mathrm{O}_{6}$ is orthorhombic and isostructural with other $\mathrm{Na}$ REETi ${ }_{2} \mathrm{O}_{6}(R E E=\mathrm{Pr}-\mathrm{Lu})$. The refined atomic coordinates and isotropic thermal parameters for $\mathrm{NaCeTi}_{2} \mathrm{O}_{6}$ are given in Table 5 . 


\section{A. R. CHAKHMOURADIAN ETAL.}

TABLE 4. X-ray diffraction data for synthetic $\mathrm{NaCeTi}_{2} \mathrm{O}_{6}(P n m a)$

\begin{tabular}{|c|c|c|c|c|c|c|c|}
\hline$h k l$ & $d(\AA)$ & $I_{\text {calc }}$ & $I_{\mathrm{obs}}$ & $h k l$ & $d(\AA)$ & $I_{\text {calc }}$ & $I_{\mathrm{obs}}$ \\
\hline 020 & 3.85 & 1 & 1 & 400 & 1.364 & 5 & 5 \\
\hline 101 & 3.85 & 2 & 1 & 242 & 1.363 & 19 & 18 \\
\hline 111 & 3.45 & 1 & 1 & 004 & 1.359 & 5 & 5 \\
\hline 200 & 2.729 & 23 & 24 & 161 & 1.219 & 8 & 8 \\
\hline 121 & 2.726 & 100 & 100 & 402 & 1.219 & 3 & 3 \\
\hline 002 & 2.720 & 22 & 22 & 323 & 1.218 & 8 & 7 \\
\hline 031 & 2.325 & 1 & 1 & 204 & 1.217 & 3 & 3 \\
\hline 220 & 2.226 & 11 & 12 & 260 & 1.163 & 1 & 1 \\
\hline 022 & 2.221 & 11 & 11 & 422 & 1.163 & 1 & 2 \\
\hline 040 & 1.928 & 18 & 18 & 062 & 1.162 & 1 & 1 \\
\hline 202 & 1.926 & 38 & 37 & 224 & 1.160 & 1 & 1 \\
\hline 212 & 1.869 & 1 & 1 & 440 & 1.114 & 4 & 5 \\
\hline 141 & 1.724 & 1 & 1 & 044 & 1.111 & 4 & 4 \\
\hline 103 & 1.721 & 1 & $<1$ & 343 & 1.069 & $<1$ & 1 \\
\hline 311 & 1.683 & 1 & 1 & 511 & 1.060 & $<1$ & 1 \\
\hline 321 & 1.575 & 19 & 20 & 521 & 1.031 & 4 & 4 \\
\hline 240 & 1.575 & 9 & 10 & 361 & 1.031 & 5 & 5 \\
\hline 042 & 1.573 & 9 & 10 & 442 & 1.030 & 4 & 4 \\
\hline 123 & 1.571 & 20 & 21 & 163 & 1.030 & 5 & 5 \\
\hline
\end{tabular}

In common with $\mathrm{NaREETi}_{2} \mathrm{O}_{6}$, the structure of $\mathrm{NaCeTi}_{2} \mathrm{O}_{6}$ is derived from the ideal perovskite lattice by tilting (rotation) of the $\mathrm{TiO}_{6}$ octahedra about the tetrad axis [010] and the diad axis [101] of the cubic subcell. These tilts are commonly referred to as $\phi$ and $\theta$, respectively. The resulting rotation can be described as the single tilt $\Phi$ about the triad axis [111] of the subcell. In $\mathrm{NaCeTi}_{2} \mathrm{O}_{6}$, the tilt angles $\phi, \theta$ and $\Phi$ are $4.3(2)^{\circ}, 4.7(1)^{\circ}$ and $6.4(2)^{\circ}$, respectively. These values are relatively small, compared with the tilt angles for some other orthorhombic perovskites, e.g. $\mathrm{CaTi}_{1-2 x} \mathrm{Fe}_{x} \mathrm{Nb}_{x} \mathrm{O}_{3} \quad\left(\Phi=10.0-11.7^{\circ}\right)$ or $\mathrm{NaMgF}_{3}\left(\Phi=17.8^{\circ}\right)$ (Chakhmouradian and Mitchell, 1998b; Zhao et al., 1993).

The XRD powder patterns of loparite from Burpala and other occurrences, indexed on both cubic and orthorhombic cells, are given in Table 6. For most patterns, the true unit-cell parameters cannot be accurately determined because of the scarcity and weakness of orthorhombic diffraction lines. Therefore, we

TABLE 5. Crystallographic characteristics for synthetic $\mathrm{NaCeTi}_{2} \mathrm{O}_{6}$

\begin{tabular}{lccccc}
\hline Atom & Position & $x$ & $y$ & $z$ & $B\left(\AA^{2}\right)^{*}$ \\
\hline $\mathrm{Na}(\mathrm{Ce})$ & $4 c$ & $0.0132(6)$ & $1 / 4$ & $0.004(2)$ & $1.27(4)$ \\
$\mathrm{Ti}$ & $4 b$ & 0 & 0 & $1 / 2$ & $0.73(5)$ \\
$\mathrm{O} 1$ & $4 c$ & $-0.008(5)$ & $1 / 4$ & $0.550(8)$ & $-0.7(9)$ \\
$\mathrm{O} 2$ & $8 d$ & $0.274(4)$ & $0.033(2)$ & $0.263(4)$ & $1.6(3)$
\end{tabular}

Final agreement factors and unit-cell parameters for $\mathrm{NaCeTi}_{2} \mathrm{O}_{6}: R_{p}=16.9, R_{w p}=23.8$,

$\mathrm{R}_{\mathrm{B}}=6.1, \chi^{2}=1.66, D W=1.36$

$a=5.4517(4)$

$b=7.7058(9)$

$c=5.4333(6) \AA$

* $B$ factors are kept at the same values for all $A$-site cations.

The refinement also included $\mathrm{CeO}_{2}[a=5.4112(1) \AA]$ and $\mathrm{TiO}_{2}[a=4.5942(4), c=2.9582(4) \AA]$. 


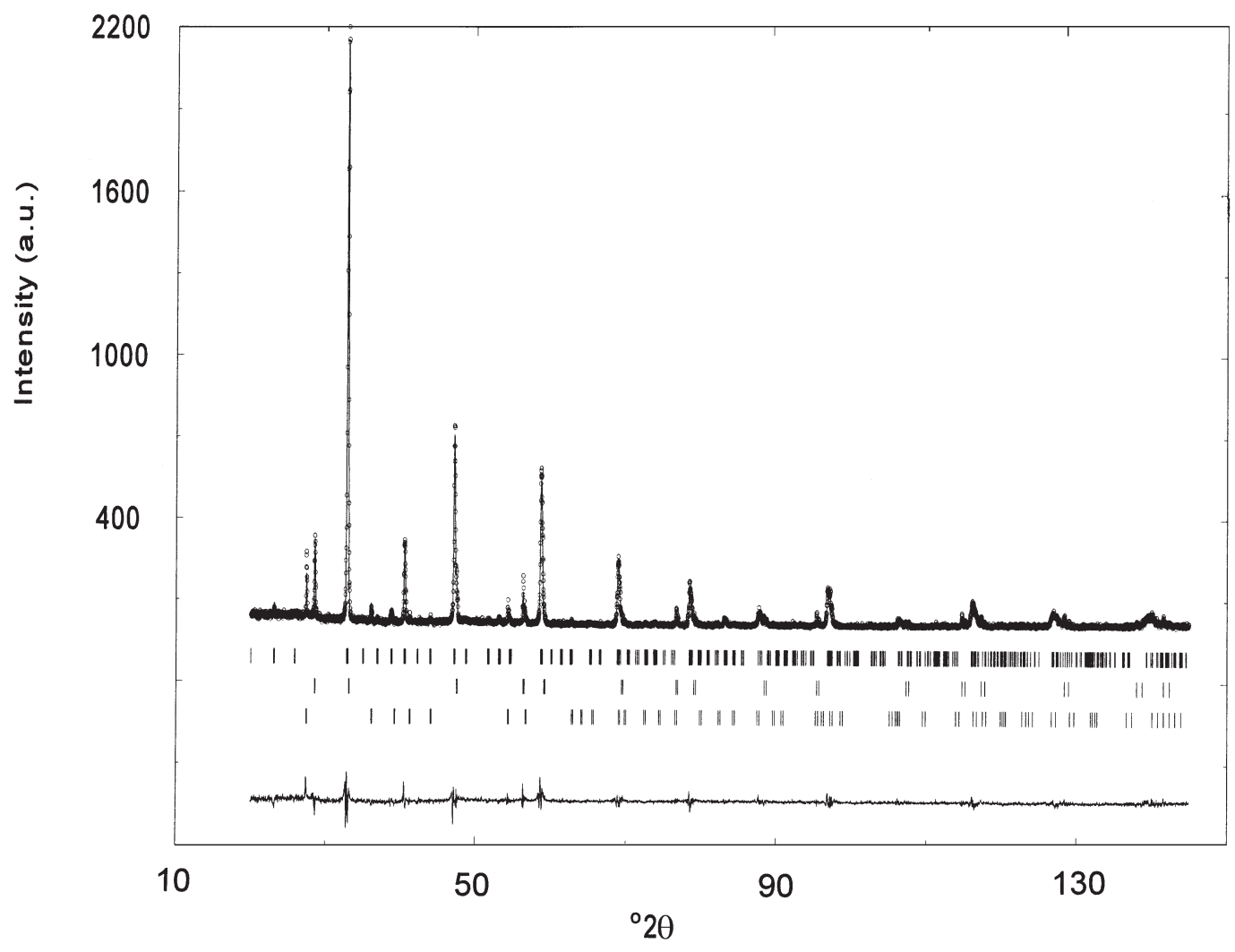

FIG. 3. Calculated (line), observed (dots) XRD patterns and difference spectrum for synthetic $\mathrm{NaCeTi}_{2} \mathrm{O}_{6}$. For unitcell parameters and agreement factors see Table 5. The upper row of tick marks corresponds to $\mathrm{NaCeTi}_{2} \mathrm{O}_{6}$, intermediate to $\mathrm{CeO}_{2}$, and lower to $\mathrm{TiO}_{2}$.

calculated the pseudocubic cell dimensions using the strongest peaks which actually represent a superposition of two or more diffraction lines. Compared to loparite from other occurrences, that from Burpala has the smallest unit cell, which correlates with the low $\mathrm{Na}_{2} \mathrm{O}$ and $\mathrm{Nb}_{2} \mathrm{O}_{5}$ contents (Table 6). In addition to $\mathrm{Na}$ and $\mathrm{Nb}$, enrichment of loparite in $\mathrm{Sr}, \mathrm{K}$ and $\mathrm{Ta}$ also results in increasing cell dimensions, as the ionic radii of these elements are significantly larger than those of $\mathrm{Ce}^{3+}$ and Ti. Figure 4 shows the correlation between the pseudocubic unit-cell parameter $a_{\mathrm{p}}$ and the percentage of relatively large-size cations at the $A$ - and $B$-sites in the structure of naturallyoccurring loparite.

'Metaloparite'. For XRD studies, we chose 'metaloparite' from the riebeckite albitite and aegirinite. The two samples are very similar in composition with the exception of slightly differing $\mathrm{CaO}$ content (cf. analyses 6 and 11 in Table 3). Both samples are metamict at room temperature. 'Metaloparite' from the albitite restores crystallinity upon heating to $750^{\circ} \mathrm{C}$. The heated sample gives an XRD pattern comparable with that of loparite (Table 7). 'Metaloparite' from the aegirinite remains essentially metamict up to $900^{\circ} \mathrm{C}$, and produces only a few faint diffraction lines in the range $900-1100^{\circ} \mathrm{C}$. The sample heated to $1100^{\circ} \mathrm{C}$ gives a complex XRD pattern which includes a few diffraction lines characteristic of the perovskite structure, plus several others belonging to an unidentified phase or phases (Table 7). The unassigned peaks do not match 


\section{A. R. CHAKHMOURADIAN ETAL.}

TABLE 6. X-ray diffraction data for loparite

\begin{tabular}{|c|c|c|c|c|c|c|c|c|c|}
\hline$h k l_{P m \overline{3} m}$ & $h k l_{\text {Pnma }}$ & $d(\AA)$ & $I$ & $d(\AA)$ & $I$ & $d(\AA)$ & $I$ & $d(\AA)$ & $I$ \\
\hline 100 & $101+020$ & & & & & & & 3.94 & $<1$ \\
\hline \multirow[t]{3}{*}{110} & $200+121+002$ & 2.745 & 100 & 2.754 & 100 & 2.760 & 100 & 2.780 & 100 \\
\hline & 210 & & & & & & & 2.560 & $<1$ \\
\hline & $211+112+031$ & 2.340 & 1 & 2.346 & 2 & 2.350 & 2 & 2.364 & 1 \\
\hline 111 & $220+022$ & 2.238 & 12 & 2.248 & 8 & 2.251 & 9 & 2.270 & 4 \\
\hline 200 & $202+040$ & 1.940 & 33 & 1.945 & 54 & 1.948 & 40 & 1.960 & 16 \\
\hline 211 & $321+123+240$ & 1.583 & 35 & 1.588 & 28 & 1.589 & 25 & 1.600 & 15 \\
\hline \multirow[t]{2}{*}{220} & $400+242+004$ & 1.371 & 16 & 1.374 & 14 & 1.376 & 9 & 1.385 & 6 \\
\hline & 143 & & & & & 1.294 & $<1$ & & \\
\hline 310 & $402+323+161+204$ & 1.226 & 7 & 1.229 & 12 & 1.230 & 9 & 1.238 & 4 \\
\hline 311 & $422+224$ & & & 1.172 & 1 & 1.173 & $<1$ & 1.174 & $<1$ \\
\hline \multirow[t]{2}{*}{222} & $440+044$ & 1.120 & $<1$ & 1.122 & 3 & 1.123 & 2 & 1.130 & 1 \\
\hline & $343+105$ & & & & & 1.078 & 1 & & \\
\hline \multirow[t]{2}{*}{321} & $521+442+361+$ & & & & & & & & \\
\hline & $244+163+125$ & 1.036 & 7 & 1.038 & 10 & 1.040 & 5 & 1.044 & 3 \\
\hline 400 & $404+080$ & & & 0.972 & 2 & 0.972 & 2 & 0.974 & 1 \\
\hline \multirow{2}{*}{\multicolumn{2}{|c|}{$\begin{array}{l}a_{\mathrm{p}}, \stackrel{\AA}{\AA} \\
V_{\mathrm{p}}, \AA^{3}\end{array}$}} & \multicolumn{2}{|c|}{$3.8815(3)$} & \multicolumn{2}{|c|}{$3.8870(5)$} & \multicolumn{2}{|c|}{$3.8909(8)$} & \multicolumn{2}{|c|}{$3.918(2)$} \\
\hline & & \multicolumn{2}{|c|}{$58.48(1)$} & \multicolumn{2}{|c|}{$58.73(2)$} & \multicolumn{2}{|c|}{$58.90(4)$} & \multicolumn{2}{|c|}{$60.15(9)$} \\
\hline \multicolumn{2}{|l|}{$\mathrm{Na}_{2} \mathrm{O}$ (range) } & \multicolumn{2}{|c|}{$7.5-7.6$} & \multicolumn{2}{|c|}{$7.4-7.7$} & \multicolumn{2}{|c|}{$7.4-8.4$} & \multicolumn{2}{|c|}{$9.7-10.4$} \\
\hline \multicolumn{2}{|l|}{$\mathrm{Nb}_{2} \mathrm{O}_{5}$ (range) } & \multicolumn{2}{|c|}{$3.8-4.0$} & \multicolumn{2}{|c|}{$8.3-9.1$} & \multicolumn{2}{|c|}{$7.3-10.4$} & \multicolumn{2}{|c|}{$18.7-20.1$} \\
\hline \multicolumn{2}{|l|}{$\mathrm{TiO}_{2}$ (range) } & \multicolumn{2}{|c|}{$40.6-41.4$} & \multicolumn{2}{|c|}{$40.9-41.0$} & \multicolumn{2}{|c|}{$38.2-41.6$} & \multicolumn{2}{|c|}{$34.5-35.0$} \\
\hline \multirow{2}{*}{\multicolumn{2}{|c|}{$\begin{array}{l}\text { Rock type } \\
\text { Locality }\end{array}$}} & \multirow{2}{*}{\multicolumn{2}{|c|}{$\begin{array}{c}\text { Rbck-albitite } \\
\text { Burpala }^{\mathrm{a}}\end{array}$}} & \multirow{2}{*}{\multicolumn{2}{|c|}{$\begin{array}{c}\text { rischorrite } \\
\text { Khibina }\end{array}$}} & \multirow{2}{*}{\multicolumn{2}{|c|}{$\begin{array}{c}\text { foyaite } \\
\text { Lovozero }\end{array}$}} & & \\
\hline & & & & & & & & Khi & pina \\
\hline
\end{tabular}

${ }^{\text {a }}$ For composition see Table 2, anal. 5.

the XRD patterns of lucasite-(Ce) (Nickel et al., 1987) or $\mathrm{CeTi}_{2} \mathrm{O}_{5.6}$ (Leonov et al., 1966). Also, diffraction lines of $\mathrm{CeO}_{2}$ and $\mathrm{TiO}_{2}$, typical

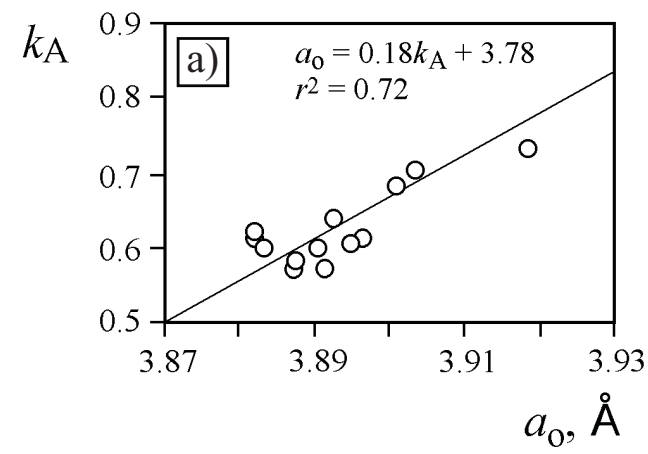

components of thermal decomposition of $\mathrm{Ce}-\mathrm{Ti}$ oxides (Leonov et al., 1966), are not observed in this pattern.

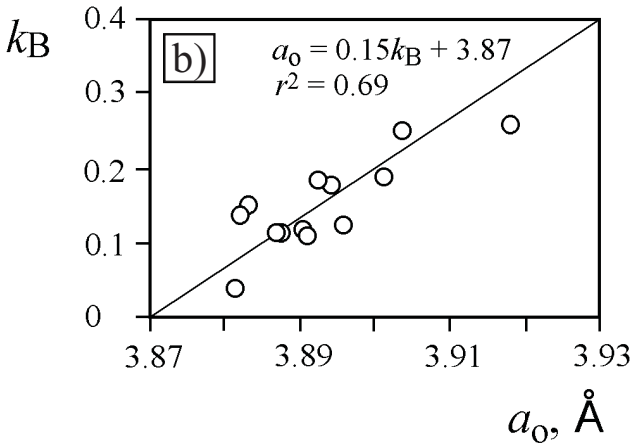

FIG. 4. Correlation between the relative amount of large-size cations at the $A$ - and $B$-sites and pseudocubic cell parameter for naturally-occurring loparite. (a) $\left[k_{\mathrm{A}}=\Sigma(\mathrm{Na}+\mathrm{La}+\mathrm{Sr}) / \Sigma A\right.$-cations $]$ vs. $a_{\mathrm{o}}$. (b) $\left[k_{\mathrm{B}}=\Sigma(\mathrm{Nb}+\mathrm{Ta}) / \Sigma B\right.$ cations] $v s . a_{\mathrm{o}}$. 


\section{LOPARITE AND ‘METALOPARITE’ FROM RUSSIA}

TABLE 7. X-ray diffraction data for heated 'metaloparite'

\begin{tabular}{lclr}
\hline \multicolumn{2}{l}{$\begin{array}{ll}\text { Riebeckite albitite } \\
d(\AA)\end{array}$} & $I$ & \multicolumn{2}{c}{ Aegirinite $^{\mathrm{b}}$} \\
& & $d(\AA)$ & $I$ \\
\hline & & 3.47 & 10 \\
& & 3.39 & 10 \\
$2.72^{*}$ & 10 & 2.93 & 6 \\
& & $2.72^{*}$ & 10 \\
& & 2.53 & 1 \\
$1.935^{*}$ & 4 & $1.945^{*}$ & 1 \\
& & 1.880 & 3 \\
$1.575^{*}$ & 5 & 1.630 & 3 \\
$1.368^{*}$ & 1 & $1.580^{*}$ & 8 \\
& & & \\
\hline
\end{tabular}

Intensity estimated visually from film

${ }^{\text {a }}$ For composition see Table 3, anal. 6

${ }^{\mathrm{b}}$ for composition see Table 3, anal. 11

* Lines indicative of the perovskite-type structure.

\section{Infrared spectroscopy}

The IR transmission spectrum of 'metaloparite' from the aegirinite is illustrated on Fig. 5. The spectrum shows a broad absorption band at 460-600 $\mathrm{cm}^{-1}$ corresponding to a stretching vibration of the $(\mathrm{Ti}, \mathrm{Nb}) \mathrm{O}_{6}$ octahedron (Sych et al., 1973). This absorption band is typical of many $\mathrm{Ti}$ - and $\mathrm{Nb}$-based oxides, including perovskite- and the pyrochlore-group minerals, aeschynite and thorutite (cf. spectra of Th-rich loparite in Mitchell and Chakhmouradian, 1998a). In our spectrum, this band is shifted towards lower frequencies, possibly due to the strong predominance of $\mathrm{Ti}$ over $\mathrm{Nb}$ in the composition of 'metaloparite'. As in perovskite-type compounds (Kaleveld et al., 1973; Sych et al., 1973), the splitting of this absorption band probably results from lower than cubic local symmetry of the $(\mathrm{Ti}, \mathrm{Nb}) \mathrm{O}_{6}$ octahedra. The spectrum also shows absorption bands at $1623 \mathrm{~cm}^{-1}$ and 3350-3500 $\mathrm{cm}^{-1}$ which correspond to the bending and stretching modes of water, respectively (Bhat and Gopalakrishnan, 1986). The broad band in the region $3350-3500 \mathrm{~cm}^{-1}$ is an overlap between the lines corresponding to the stretching vibration of the $\mathrm{O}-\mathrm{H}$ bond in hydroxyl groups and molecular water. A band at $1180 \mathrm{~cm}^{-1}$ cannot be assigned unequivocally, but is presumably related to the bending mode of the (Ti,Nb)-OH bond. The spectrum also includes minor absorption lines indicative of $R E E$-carbonate inclusions in the sample.

\section{Discussion and conclusions}

In alkaline complexes, loparite is a common accessory constituent in aegirine-albite and alkali amphibole-microcline-albite parageneses (Mitchell and Chakhmouradian, 1996; Chakhmouradian and Mitchell, 1998a). The albitites and related rocks

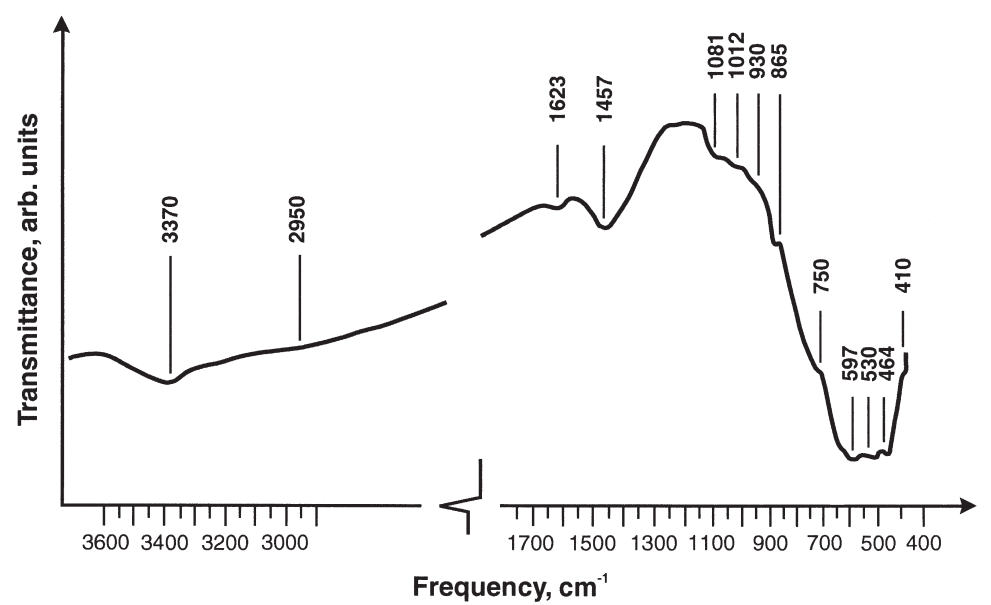

FIG. 5. Infrared transmission spectrum of 'metaloparite' from aegirinite. Powder sample, spectrophotometer Specord 75 IR. 


\section{A. R. CHAKHMOURADIAN ETAL.}

are developed along the petrographic contacts and fault zones, and have transitional, diffuse contacts with the wall-rock lithologies (KostylevaLabuntsova et al., 1978; Kirnarskii et al., 1982). They typically exhibit replacement textures, and may show relict textural features inherited from the primary rocks (e.g. flow alignment of microcline laths). Most researchers agree that the geological setting and textural features indicate a metasomatic origin for these rocks due to interaction between the primary lithologies and a late-stage alkaline fluid at low-to-moderate pressures, in the temperature range $400-500^{\circ} \mathrm{C}$ (Kostyleva-Labuntsova et al., 1978; Kirnarskii et al., 1982).

In the albitites and related rocks, accessory minerals, including loparite, commonly form poikilitic and skeletal crystals containing chadacrysts of the early rock-forming silicates (Chakhmouradian et al., 1995). Distribution of the chadacrysts may be chaotic or oriented, depending on the symmetry of fluid flow and anisotropy of the groundmass where the growth took place. All these features are observed in loparite from Burpala, suggesting that this mineral was precipitated from a metasomatic fluid rather than assimilated from the substrate rocks (e.g. nepheline syenites or pegmatites). The fluid was enriched in REE, Th, and depleted in $\mathrm{Nb}$ plus $\mathrm{Sr}$, as indicated by the composition of loparite and associated minerals, e.g. murataite (Portnov et al., 1981). Portnov et al. (1981) suggested that the lanthanides were assimilated by the fluid from the primary rocks undergoing the metasomatic alteration. It is also possible that the REE and Th were concentrated in the fluid during the differentiation of a parental alkaline magma.

In some parageneses, loparite became an unstable phase at the final stages of metasomatism, and was replaced by 'metaloparite'. The compositional data suggest that 'metaloparite' results from leaching of $\mathrm{Na}$ from the $A$-sites in the structure of loparite accompanied by accommodation of protons in the vacancies and creation of hydroxyl bonding. The noticeable variation in $\mathrm{CaO}$ and $\mathrm{SrO}$ contents between the two minerals suggests that the conversion of loparite into 'metaloparite' also involved some ion exchange between the fluid and loparite. This process can be summarized as:

$$
\begin{aligned}
& \mathrm{Na}(\text { REE, } \mathrm{Sr}) \mathrm{Ti}_{2} \mathrm{O}_{6}+n \mathrm{H}_{2} \mathrm{O}+\mathrm{Ca}^{2+} \rightarrow \\
& \text { loparite fluid } \\
& \left(\text { REE, Ca) } \mathrm{Ti}_{2} \mathrm{O}_{5}(\mathrm{OH}) \cdot n \mathrm{H}_{2} \mathrm{O}+\mathrm{Sr}^{2+}+\mathrm{Na}^{+}+(\mathrm{OH})^{-}\right. \\
& \text {'metaloparite' } \\
& \text { fluid }
\end{aligned}
$$

It is not clear why 'metaloparite' occurs only in some parageneses, and is not observed in others. The most plausible explanation is that variation in the leaching rate of $\mathrm{Na}$ depends on the alkalinity. From reaction (1), we should expect that the decrease in alkalinity results in increasing the leaching rate of $\mathrm{Na}$ from loparite. Note that in experimental systems, cation leaching from perovskite-type compounds occurs in the $\mathrm{pH}$ range 4.5-6.0 (Myhra et al., 1984; Kastrissios et al., 1987).

The leaching of $\mathrm{Na}$ and hydration of loparite resulted in the metamictization of this mineral. Upon heating, some samples of 'metaloparite' restore the perovskite-type structure. Based on these data and IR spectroscopy, we suggest that 'metaloparite' may have a short-range atomic arrangement similar to that of perovskite, and represents a cation-deficient oxide-hydroxide of LREE and $\mathrm{Ti}$, related to the perovskite-group minerals. At present, however, available mineralogical data are insufficient for rehabilitation of 'metaloparite' as a valid mineral species. Further studies of this phase by high-resolution transmission electron microscopy are required.

\section{Acknowledgements}

This work is supported by the Natural Sciences and Engineering Research Council of Canada and Lakehead University (ARC, RHM). We are grateful to the staff of the X-ray Diffraction Laboratory at St. Petersburg State University (Russia), and Instrumentation Laboratory at Lakehead University (Ontario) for assistance with the analytical work. R. Chapman (University of Manitoba) is thanked for his help with obtaining the WDS analyses. AVP acknowledges the help and many useful comments from his scientific advisor, Dr M.D. Evdokimov during this study. The samples of loparite and 'metaloparite' from Burpala examined in the present study, were kindly provided by the Department of Mineralogy, St. Petersburg State University (Russia), and by Dr N.V. Vladykin. Numerous comments made by an anonymous reviewer helped to improve the early version of the manuscript.

\section{References}

Banfield, J.F. and Veblen, D.R. (1992) Conversion of perovskite to anatase and $\mathrm{TiO}_{2}$ (B): A TEM study 


\section{LOPARITE AND ‘METALOPARITE’ FROM RUSSIA}

and the use of fundamental building blocks for understanding relationships among the $\mathrm{TiO}_{2}$ minerals. Amer. Mineral., 77, 545-57.

Belous, A.G., Novitskaya G.N., Gavrilova, L.G., Polyanetskaya, S.V. and Makarova, Z.Ya. (1985) Lanthanum titanate-zirconates with the perovskite structure. Soviet Progr. Chem., 51, 13-5.

Bhat, V. and Gopalakrishnan, J. (1986) $\mathrm{HNbWO}_{6}$ and $\mathrm{HTaWO}_{6}$ : novel oxides related to $\mathrm{ReO}_{3}$ formed by ion exchange of rutile-type $\mathrm{LiNbWO}_{6}$ and $\mathrm{LiTaWO}_{6}$. J. Solid State Chem., 63, 278-83.

Campbell, L.S., Henderson, P., Wall, F. and Nielsen, T.F.D. (1997) Rare earth chemistry of perovskite group minerals from the Gardiner complex, east Greenland. Mineral. Mag., 61, 197-212.

Chakhmouradian, A.R. and Mitchell, R.H. (1997) Compositional variation of perovskite-group minerals from the carbonatite complexes of the Kola Alkaline Province, Russia. Canad. Mineral., 35, $1293-310$.

Chakhmouradian, A.R. and Mitchell, R.H. (1998a) Compositional variation of perovskite-group minerals from the Khibina alkaline complex, Kola Peninsula. Canad. Mineral., 36, (in press).

Chakhmouradian, A.R. and Mitchell, R.H. (1998b) A structural study of the perovskite $\mathrm{CaTi}_{1-2 x} \mathrm{Fe}_{x} \mathrm{Nb}_{x} \mathrm{O}_{3}$. J. Solid State Chem., 138, 272-7.

Chakhmouradian, A.R., Rudashevsky, N.S. and Pilipiuk, A.N. (1995) Loparite mineralization of the Niorkpakhk Mt. (Khibiny): The role of metasomatism in its formation. Zap. Vses. Mineral. Obshch., 124, $72-8$.

Drake, M.J. and Weill, D.F. (1972) New rare earth element standards for electron microprobe analysis. Chem. Geol., 10, 179-81.

Gerasimovskii, V.I. (1941) Metaloparite, a new mineral from the Lovozero tundras. Compt. Rend. Acad. Sci. URSS, 33, 61-3.

Gieré, R. and Williams, C.T. (1992) REE-bearing minerals in a Ti-rich vein from the Adamello contact aureole (Italy). Contrib. Mineral. Petrol., 112, $83-100$.

Haggerty, S.E. and Mariano, A.N. (1983) Strontianloparite and strontio-chevkinite: Two new minerals in rheomorphic fenites from the Paraná Basin carbonatites, South America. Contrib. Mineral. Petrol., 84, 365-81.

Harley, S.L. (1994) Mg-Al yttrian zirconolite in a partially melted sapphirine granulite, Vestfold Hills, east Antarctica. Mineral. Mag., 58, 259-69.

Hu, M., Wenk, H.-R. and Sinitsyna, D. (1992) Microstructures in natural perovskites. Amer. Mineral., 77, 359-73.

Kaleveld, E.W., Bruntinck, D.J., Dotman, J.P. and Blasse, G. (1973) An infrared investigation of the order on the larger cation sublattice of the perovskite structure. J. Inorg. Nucl. Chem., 35, 3928-30.

Kastrissios, T.K., Stephenson, M. and Turner, P.S. (1987) Hydrothermal dissolution of perovskite: Implications for Synroc formulation. J. Amer. Ceram. Soc., 70, C144-6.

Kesson, S.E., Sinclair, W.J. and Ringwood, A.E. (1983) Solid solution limits in SYNROC zirconolite. $\mathrm{Nucl}$. Chem. Waste Manag., 4, 259-65.

Khomyakov, A.P. (1972) Abundance of rare-earth elements in rocks and auxiliary minerals of the Burpala alkaline complex (Northern Transbaikalia). Izvestiya AN SSSR, Ser. Geol., 1972(1), (in Russian), 94- 101 .

Kirnarskii, Yu.M., Kondakov, Yu.S. and Savitskii, V.A. (1982) Aegirine-albite metasomatites of the Lovozero massif and its surroundings. Dokl. AN SSSR, 267, (in Russian), 1183-6.

Kirsanov, N.A. and Bazuev, G.V. (1988) Synthesis and $\mathrm{X}$-ray studies of the perovskite solid solutions $\mathrm{Ln}_{2 / 3-x} \mathrm{Na}_{3 x} \mathrm{TiO}_{3}$. Zhurnal Neorg. Chimii (J. Inorg. Chem.), 33, (in Russian), 2909-12.

Kirsanov, N.A., Bazuev, G.V. and Finkel'shtein, L.D. (1988) Synthesis and properties of the perovskite solid solution $\mathrm{Ce}_{2 / 3-} \mathrm{Na}_{3 \times} \mathrm{TiO}_{3}$. Zhurnal Neorg. Chimii (J. Inorg. Chem.), 33, (in Russian), 1004-7.

Kogarko, L.N., Kononova, V.A., Orlova, M.P. and Woolley, A.R. (1995) Alkaline rocks and carbonatites of the world. Part 2: Former USSR. Chapman \& Hall, London, U.K., 226 pp.

Kopylova M.G., Rickard, R.S., Kleyenstueber, A., Taylor, W.R., Gurney, J.J. and Daniels, L.R.M. (1997) First occurrence of strontian K-Cr loparite and $\mathrm{Cr}$-chevkinite in diamonds. Russian Geol. Geophys., 38, 405-20.

Kostyleva-Labuntsova, E.E., Borutskii, B.E., Sokolova, M.N., Shliukova, Z.V., Dorfman, M.D., Dudkin, O.B., Kozyreva, L.V. and Ikorskii, S.V. (1978) The mineralogy of the Khibina massif. Vol. 1. Nauka Press, Moscow, (in Russian), 228 pp.

Lapin, A.V. and Kulikova, I.M. (1989) Processes of pyrochlore alteration and their products in the carbonatite weathering crusts. Zap. Vses. Mineral. Obshch., 118, (in Russian), 41-9.

Lebedeva, I.O. and Nedosekova, I.L. (1993) On the process of aeschynitization of pyrochlore from carbonatites of the Buldymskii massif (Vishnevye Mts., Urals). Zap. Vses. Mineral. Obshch., 122, (in Russian), 69-75.

Leonov, A.I., Piryutko, M.M. and Keler, E.K. (1966) Influence of the gas medium and temperature on the reaction in the system $\mathrm{Ce}-\mathrm{Ti}-\mathrm{O}$ and comparison of the properties of titanates of rare earth elements. Inorg. Anal. Chem. (Bull. AN SSSR, Chem. Sci. Div.), 1966(5), 756-60.

Lumpkin, G.R. and Ewing, R.C. (1996) Geochemical alteration of pyrochlore-group minerals: Betafite 


\section{A. R. CHAKHMOURADIAN ETAL.}

subgroup. Amer. Mineral., 81, 1237-48.

Lumpkin, G.R., Colella, M., Smith, K.L., Mitchell, R.H. and Larsen, A.O. (1997) Chemical composition, geochemical alteration, and radiation damage effects in natural perovskite. In Scientific Basis for Nuclear Waste Management, (in press).

Merlino, S., Perchiazzi, N., Khomyakov, A.P., Pushcharovskii, D.Y., Kulikova, I.M. and Kuzmin, V.I. (1990) Burpalite, a new mineral from Burpalinskii massif, North Transbajkal, USSR: its crystal structure and OD character. Eur. J. Mineral., 2, 177-85.

Mitchell, R.H. (1996) Perovskites: a revised classification scheme for an important rare earth element host in alkaline rocks. In Rare Earth Minerals: Chemistry, Origin and Ore Deposits (A.P. Jones, F. Wall and C.T. Williams, eds), Chapman \& Hall, London, 41-76.

Mitchell, R.H. and Chakhmouradian, A.R. (1996) Compositional variation of loparite from the Lovozero alkaline complex, Russia. Can. Mineral. 34, 977-90.

Mitchell, R.H. and Chakhmouradian, A.R. (1998a) Thrich loparite from the Khibina alkaline complex, Kola Peninsula: isomorphism and paragenesis. Mineral. Mag. 62, 341-53.

Mitchell, R.H. and Chakhmouradian, A.R. (1998b) A structural study of the perovskite series $\mathrm{Na}_{1 / 2+x} \mathrm{La}_{1 / 2-3 x} \mathrm{Th}_{2 x} \mathrm{TiO}_{3}$. J. Solid State Chem., 138 $307-12$.

Myhra, S., Savage, D., Atkinson, A. and Riviere, J.C. (1984) Surface modification of some titanate minerals subjected to hydrothermal chemical attack. Amer. Mineral., 69, 902-9.

Nesbitt, H.W., Bancroft, M.G., Fyfe, W.S., Karkhanis, S.N. and Nishijima, A. (1981) Thermodynamic stability and kinetics of perovskite dissolution. Nature, 289, 358-62.

Nickel, E.H., Grey, I.E. and Madsen, I.C. (1987) Lucasite-(Ce), $\mathrm{CeTi}_{2}(\mathrm{O}, \mathrm{OH})_{6}$, a new mineral from Western Australia: Its description and structure. Amer. Mineral., 72, 1006-10.

Platt, R.G. (1994) Perovskite, loparite and Ba-Fe hollandite from the Schryburt Lake carbonatite complex, northwestern Ontario, Canada. Mineral. Mag., 58, 49-57.

Portnov, A.M., Dubakina, L.S. and Krivokoneva, G.K. (1981) Murataite in predictable association with landauite. Dokl. AN SSSR, Earth Sci. Sect., 261, $168-70$.

Ringwood, A.E., Kesson, S.E., Ware, N.G., Hibberson, W. and Major, A. (1979) Immobilisation of high level nuclear reactor wastes in SYNROC. Nature, 278, 219-23.
Rodriguez-Carvajal, J. (1990) 'FULLPROF' program: Rietveld pattern matching analysis of powder patterns. ILL, Grenoble.

Rosenblum, S. and Mosier, E.L. (1975): Nonmetamict nioboaeschynite-(Ce) from Alaska. Amer. Mineral., 60, 309-15.

Saltykova, V.S. (1959) Analyses of minerals with rare elements, obtained at the Chemical Laboratory of the Institute of Mineralogy, Geochemistry and Crystal Chemistry of Rare Elements AN SSSR during 1954-1957. Trudy IMGRE, 2, (in Russian), $189-208$.

Semenov, E.I. (1972) The Mineralogy of the Lovozero Alkaline Massif. Nauka Press, Moscow, (in Russian), $308 \mathrm{pp}$.

Shan, Y.J., Nakamura, T., Inaguma Y. and Itoh, M. (1998) Preparation and dielectric characterizations of the novel perovskite-type oxides $\left(\mathrm{Ln}_{1 / 2} \mathrm{Na}_{1 / 2}\right) \mathrm{TiO}_{3}$ $(\mathrm{Ln}=\mathrm{Dy}, \mathrm{Ho}, \mathrm{Er}, \mathrm{Tm}, \mathrm{Yb}, \mathrm{Lu})$. Solid State Ionics, 108, 123-8.

Sun, P.H., Nakamura, T., Shan, Y.J., Inaguma, Y. and Itoh, M. (1997) High-temperature quantum paraelectricity in perovskite-type titanates $\mathrm{Ln}_{1 / 2} \mathrm{Na}_{1 / 2} \mathrm{TiO}_{3}$ $(\mathrm{Ln}=\mathrm{La}, \mathrm{Pr}, \mathrm{Nd}, \mathrm{Sm}, \mathrm{Eu}, \mathrm{Gd}$, and Tb). Ferroelectr. 200, 93-107.

Sych, A.M., Belokon', A.T., Dem'yanenko, V.P. and Eremenko, L.A. (1973) Vibration spectra of perovskite-structure rare-earth niobates. Ukrain. Phys. Zh. (Ukrain. J. Phys.), 18, (in Russian), 787-92.

Tolok, A.A. and Bazhenova, F.V. (1965) Loparite - a new accessory mineral in nepheline syenites of the Sikhote-Alin'. Zap. Vses. Mineral. Obshch., 94, (in Russian), 217-9.

Wall, F., Williams, C.T. and Woolley, A.R. (1996) Pyrochlore from weathered carbonatite at Lueshe, Zaire. Mineral. Mag., 60, 731-50.

Woodward, P.M. (1997) Octahedral tilting in perovskites. I. Geometrical considerations. Acta Crystallogr., B53, 32-43.

Zhao, Yu., Weidner, D.J., Parise, J.B. and Cox, D.E. (1993) Critical phenomena and phase transition of perovskite - data for $\mathrm{NaMgF}_{3}$ perovskite. Part II. Phys. Earth Planet. Inter., 76, 17-34.

Zhidkov, A.Ya. (1961a) Loparite from the North-Baikal ridge. Zap. Vses. Mineral. Obshch., 90, (in Russian), 288-91.

Zhidkov, A.Ya. (1961b) The new North-Baikal alkaline province, and certain traits of the occurrence of nepheline in its rocks. Dokl. AN SSSR, 140, (in Russian), 181-4.

[Manuscript received 18 May 1998: revised 14 October 1998] 